\title{
Studies on bioflocculant production by a mixed culture of Methylobacterium sp. Obi and Actinobacterium sp. Mayor
}

\author{
Ntsaluba Luvuyo, Uchechukwu U Nwodo, Leonard V Mabinya and Anthony I Okoh*
}

\begin{abstract}
Background: Bioflocculants effect the aggregation of suspended solutes in solutions thus, a viable alternative to inorganic poly-ionic and synthetic organic flocculants which are associated with deleterious health problems. Consequently, a consortium of two bacteria species were evaluated for optimized bioflocculant yield following the inadequacies of axenic cultures.

Results: $16 \mathrm{~S}$ rDNA nucleotide sequencing and BLAST analysis of nucleotide sequences were used to identify the bacterial species, carbon and nitrogen sources optimally supporting bioflocculant production were assessed and the purified bioflocculant characterized.

Nucleotide sequences showed $97 \%$ and 96\% similarity to Methylobacterium sp. AKB-2008-KU9 and Methylobacterium sp. strain 440. The second isolate, likewise, showed $98 \%$ similarity to Actinobacterium OR-221. The sequences were deposited in GenBank as Methylobacterium sp. Obi [accession number HQ537130] and Actinobacterium sp. Mayor [accession number JF799090]. Flocculating activity of $95 \%$ was obtained in the presence of $\mathrm{Ca}^{2+}$ and heat-stability was exhibited with retention of above $70 \%$ activity at $100^{\circ} \mathrm{C}$ in $30 \mathrm{~min}$. In addition, bioflocculant yield was about $8.203 \mathrm{~g} / \mathrm{l}$. A dose of $1 \mathrm{mg} / \mathrm{ml}$ of purified bioflocculant was optimal for the clarification of Kaolin suspension (100 ml) following Jar test. FTIR spectrum revealed the presence of carboxyl and hydroxyl functional groups amongst others.

Conclusions: The mixed culture produced bioflocculant with high flocculating activity and an improved yield. The efficiency observed with jar test may imply industrial applicability.
\end{abstract}

Keywords: Bioflocculant, Consortium, Flocculating activity, Thermostable, Functional groups

\section{Background}

Flocculants may be synthetic or natural in origin. However, they lead to the fluffy mass formation of suspended particles [1]. Flocculants are extensively applied in the treatment of wastewaters and other industrial effluents $[2,3]$. Other applications have included the recovery of suspended solutes from solutions [4]. Nonetheless, inorganic flocculants which includes the salts of polyaluminium chloride and aluminium sulphate as well as the organic synthetic flocculants (poly-acryl amide and polyethylene amine) have been implicated in various human health problems such as nuerotoxicity, cancer and a medical disorder leading to dementia (Alzheimer's

\footnotetext{
* Correspondence: AOkoh@ufh.ac.za

Applied and Environmental Microbiology Research Group (AEMREG), Department of Biochemistry and Microbiology, University of Fort Hare, Private Bag X1314, Alice 5700, South Africa
}

disease). The organic synthetic flocculants are also known to be non biodegradable hence, not environmentally friendly [5]. In contrast, bioflocculants have not been associated with any medical problem and are biodegradable; as such, are considered environmentally friendly $[6,7]$.

Considerable attention has been directed towards studying bioflocculant producing bacteria in axenic culture and yield optimization has been attempted through the manipulation of fermentation and nutritional conditions. Following the aforementioned techniques, high flocculation activities have been documented. However, low bioflocculant yield and lack of cost effectiveness in the production of bioflocculant militates against the application of these bioflocculants in industrial processes, such as in wastewater treatment $[8,9]$.

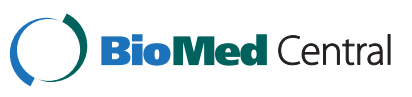

(c) 2013 Luvuyo et al.; licensee BioMed Central Ltd. This is an Open Access article distributed under the terms of the Creative Commons Attribution License (http://creativecommons.org/licenses/by/2.0), which permits unrestricted use, distribution, and reproduction in any medium, provided the original work is properly cited. 
Consequently, it has become imperative to explore alternative means of bioflocculant yield optimization [10-12]. The application of mixed culture in the production of bioflocculant has been attempted by Kurane and Matsuyama [3] as well as Zhang et al. [13] and bioflocculant yield was reported to have improved. Following these findings, we evaluated the bioflocculant production potentials of a consortium of two fresh water bacteria belonging to Methylobacterium and Actinobacterium genera and the bioflocculant was characterized for novelty.

\section{Methods}

\section{Bacterial strains}

Bacterial strains were previous isolates from the Tyume River in the Eastern Cape Province of South Africa. Isolates were preserved in glycerol at $-80^{\circ} \mathrm{C}$ as part of the culture collection of the Applied and Environmental Microbiology Research Group (AEMREG), University of Fort Hare, South Africa. However, prior to storage, the test bacteria were identified as Actinobacterium sp. Mayor and Methylobacterium sp. Obi through partial nucleotide sequencing of their 16S rRNA genes with subsequent BLAST analyses. Nucleotide sequences were deposited in GenBank and the repository accession numbers were JF799090 and HQ537130 respectively.

\section{Mixed culture fermentation for bioflocculant production} Actinobacterium sp. and Methylobacterium sp. were activated by inoculation of $20 \mu \mathrm{L}$ of the glycerol stock into a sterile $5 \mathrm{~mL}$ broth composed of $(\mathrm{g} / \mathrm{L})$; beef extract (3), tryptone (10) and $\mathrm{NaCl}(5)$ and each was incubated overnight at $28^{\circ} \mathrm{C}$ respectively. One percent (1\%), each, of the activated culture was inoculated into $400 \mathrm{ml}$ of bioflocculant production medium in $1000 \mathrm{ml}$ conical flask. Bioflocculant production media was prepared in accordance with the methods of Zhang et al. [13]. Briefly, glucose $(20.0 \mathrm{~g}), \mathrm{KH}_{2} \mathrm{PO}_{4}(2.0 \mathrm{~g}), \mathrm{K}_{2} \mathrm{HPO}_{4}$ $(5.0 \mathrm{~g}),\left(\mathrm{NH}_{4}\right)_{2} \mathrm{SO}_{4}(0.2 \mathrm{~g}), \mathrm{NaCl}(0.1 \mathrm{~g}), \mathrm{MgSO}_{4} \cdot 7 \mathrm{H}_{2} \mathrm{O}$ urea $(0.5 \mathrm{~g})(0.2 \mathrm{~g})$ and yeast extract $(0.5 \mathrm{~g})$ were dissolved in one litre of distilled water and the $\mathrm{pH}$ adjusted to 7. The incubation conditions for the mixed culture fermentation were an incubation temperature of $28^{\circ} \mathrm{C}$, agitation speed of $160 \mathrm{rpm}$ in a shaker incubator and fermentation time of $72 \mathrm{~h}$. Thereafter, the fermentation broth was centrifuged at $3000 \mathrm{rpm}$ for $30 \mathrm{~min}$ at $15^{\circ} \mathrm{C}$ and the cell-free supernatant was assayed for flocculation activity.

\section{Effect of inoculum size and $\mathrm{pH}$ on bioflocculant production}

Mixed culture inoculum volumes of $0.5 \%, 1 \%, 1.5 \%$ and $2 \%$ in proportion to the fermentation volume $(400 \mathrm{ml})$ were respectively evaluated for bioflocculant production.
The cultures were incubated at a temperature of $28^{\circ} \mathrm{C}$ for $72 \mathrm{~h}$ at $160 \mathrm{rpm}$. Thereafter, the fermentation broth was centrifuged (3000 rpm, $30 \mathrm{~min}, 15^{\circ} \mathrm{C}$ ) and the supernatant was assessed for flocculation activity. Likewise, the initial fermentation $\mathrm{pH}$ regimes of 2 to 12 were evaluated for bioflocculant production while other conditions were kept constant.

\section{Flocculation activity determination}

Flocculating activity was determined in accordance with the methods of Kurane et al. [8] as modified by Wang et al. [14]. A suspension of Kaolin clay (4 g/L) in deionized water at $\mathrm{pH} 7.0$ was used. One hundred micro liters $(100 \mu \mathrm{L})$ of the bioflocculant-rich broth and $250 \mu \mathrm{L}$ of $1 \% \mathrm{CaCl}_{2}$ were added to $900 \mu \mathrm{L}$ of the Kaolin clay suspension; the mixture was votexed at $50 \mathrm{rpm}$ for $60 \mathrm{sec}$ and allowed to stand for $5 \mathrm{~min}$ at room temperature. Bioflocculant-rich broth was replaced with deionized water as a control and optical densities (OD) of the clarifying upper phase of the solution was measured at $550 \mathrm{~nm}$ using a ThermoSpectronic spectrophotometer (Helios Epsilon, USA). Flocculating activity was determined as follows:

Flocculating activity $=[(B-A) / B] \times 100 \%$

$A$ and $B$ were optical densities at $550 \mathrm{~nm}$ of the sample and control respectively.

\section{Purification of bioflocculant}

The concentration and purification of bioflocculant from the bioflocculant-rich broth was in accordance with the methods of Chang et al. [15]. One volume of distilled water was added to the cell-free-bioflocculant-rich broth and centrifuged at $10000 \mathrm{rpm}$ for $15 \mathrm{~min}$ at $15^{\circ} \mathrm{C}$, the supernatant was decanted and the residue re-suspended with $20 \mathrm{ml}$ of distilled water. Two volumes of cold ethanol were added to the bioflocculant solution and the mixture was left standing at $4^{\circ} \mathrm{C}$ for $12 \mathrm{~h}$. after which the precipitate was collected through centrifugation (10 $000 \mathrm{rpm} ; 15 \mathrm{~min} ; 15^{\circ} \mathrm{C}$ ). The residue was washed twice with distilled water, lyophilized and vacuum dried. The dried bioflocculant was used for subsequent assays.

\section{Optimum bioflocculant concentration for flocculation activity - Jar test}

In accordance with the methods of Wang et al. [14], Jartest was employed, with some modification, to determine bioflocculant concentration optimally mediating flocculation of Kaolin clay suspension $(4.0 \mathrm{~g} / \mathrm{L})$. Bioflocculant concentrations of $(\mathrm{mg} / \mathrm{ml}) ; 0.5,1.0,1.5$ and 2.0 were respectively added to $100 \mathrm{ml}$ Kaolin clay suspension $(4.0 \mathrm{~g} / \mathrm{L})$ containing $3 \mathrm{ml}$ of $1 \% \mathrm{CaCl}_{2}$ in $500 \mathrm{ml}$ beakers. The mixture was rapidly stirred at $180 \mathrm{rpm}$ for 
$3 \mathrm{~min}$, followed by slow stirring at $40 \mathrm{rpm}$ for $5 \mathrm{~min}$. The solutions were then allowed to stand for $10 \mathrm{~min}$. and afterwards, flocculating activity was measured and calculated as previously described.

\section{Effect of temperature, $\mathrm{pH}$ and cations on flocculating activity}

The effect of temperature regimes on the flocculating activity of purified bioflocculant were investigated; desired concentration of purified bioflocculant was reconstituted with $10 \mathrm{ml}$ of distilled water and incubated in water bath at the respective temperatures; $50^{\circ} \mathrm{C}, 80^{\circ} \mathrm{C}$ and $100^{\circ} \mathrm{C}$ for a period of up to $30 \mathrm{~min}$. Residual flocculating activity were measured afterwards [16]. Similarly, the effect of $\mathrm{pH}$ on flocculation activity of bioflocculant was determined by adjusting the $\mathrm{pH}$ of Kaolin clay suspension from 3 to 12 using $\mathrm{HCl}$ or $\mathrm{NaOH}$, before the addition of bioflocculant and $\mathrm{CaCl}_{2}$ as previously described. Furthermore, $\mathrm{KCl}, \mathrm{NaCl}, \mathrm{LiCl}, \mathrm{MgCl}_{2}, \mathrm{MnCl}_{2}$, $\mathrm{AlCl}_{3}$ and $\mathrm{FeCl}_{3}$ were respectively assessed as cation sources in place of $\mathrm{CaCl}_{2}$ [10], all conditions for flocculation activity assay were kept constant.

\section{FT-IR spectroscopy and thermo-gravimetric analyses of purified bioflocculant}

The functional groups of the bioflocculant were determined using Fourier transform infrared spectrophotometer (Perkin Elmer System 2000, FT-IR, England). The bioflocculant was ground with $\mathrm{KBr}$ at room temperature and pressed into a thin disc for FTIR spectroscopy over a wave number range of $4000-370 \mathrm{~cm}^{-1}$. The thermogravimetric analysis of the purified bioflocculant was carried out at the temperature range of 20 to $900^{\circ} \mathrm{C}$ with a heating rate of $10^{\circ} \mathrm{C} / \mathrm{min}$ under a constant flow of nitrogen gas, using a thermogravimetric analyzer (TGA 7;
Perkin Elmer) fitted with thermal analysis controller (TAC 7/DX).

\section{Results and discussion}

Effect of inoculum size on bioflocculant production

An optimum flocculation activity of $92 \%$ was achieved with $1 \%(\mathrm{v} / \mathrm{v})$ of the mixed culture (Figure 1). Higher inoculum cell densities (1.5\% and $2.0 \%)$ evaluated, did not yield corresponding increase in flocculating activity. Rather, a slight decrease was observed. This observation is expected as inappropriate ratio of inoculum cell densities to nutrient ratio leads to a phenomenon termed "inoculum effect" consequently, a reduction in the desired effect. Similar trend was observed by Zhang et al. [13] in a study on bioflocculant production by a consortium of Staphylococcus and Pseudomonas species, while Wang et al. [17] obtained maximum flocculating activity for a bioflocculant produced by an axenic culture of Klebsiella mobilis when 5\% inoculum size was used.

\section{Effect of $\mathrm{pH}$ on bioflocculant production}

An alkaline $\mathrm{pH}$ of 9 , at the start of fermentation, optimally supported bioflocculant production with flocculation activity of $89 \%$ (Figure 2). At acidic initial fermentation $\mathrm{pH}$, lower flocculation activity was observed. In addition, fermentation time was prolonged yet, comparable flocculation activity with the ambient $\mathrm{pH}$ was not achieved. The longer time observed at acidic initial fermentation $\mathrm{pH}$ may be interpreted as time needed for the mixed culture to adjust physiologically to the acidic medium. Nonetheless, various initial medium $\mathrm{pH}$ has been reported for the production of bioflocculant by different microbial species. Wang et al. [14], reported optimum bioflocculant production by Rhizobium radiobacter F2 and Bacillus sphaeicus F6 at neutral and weak alkaline $\mathrm{pH}$ while Nwodo et al.

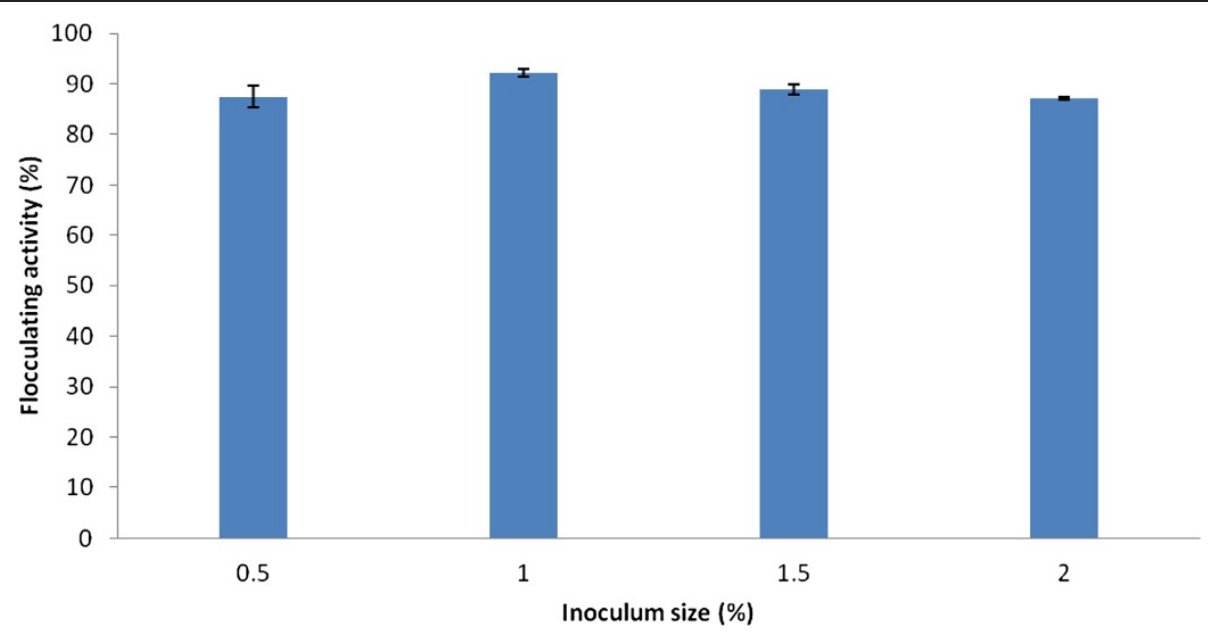

Figure 1 Effect of the inoculum size of Actinobacterium sp. and Methylobacterium sp. consortium on bioflocculant production. 


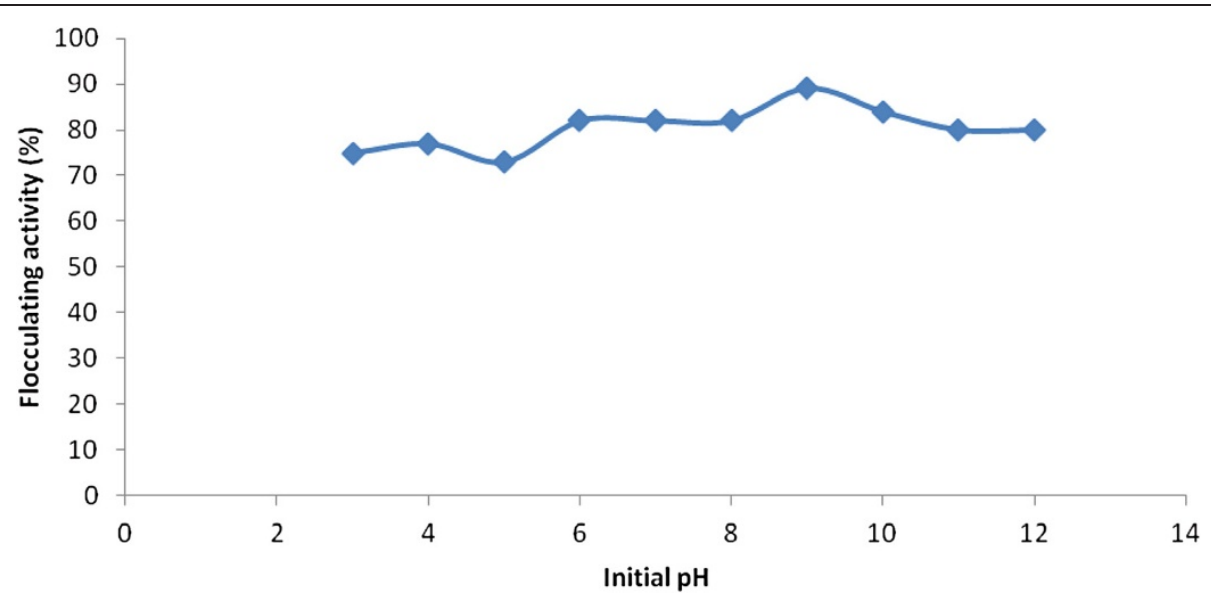

Figure 2 Effect of initial fermentation pH on bioflocculant production by the consortium of Actinobacterium sp. and Methylobacterium sp.

[18] reported weak acidic condition ( $\mathrm{pH}$ 6.8) as optimally supporting bioflocculant production by Streptomyces sp. Gansen.

\section{Bioflocculant yield and flocculation of kaolin clay}

Mixed culture fermentation, following optimal conditions (starter culture density of $1 \%$, initial fermentation $\mathrm{pH}$ of 9 , agitation speed of $160 \mathrm{rpm}$ and incubation temperature of $28^{\circ} \mathrm{C}$ ), yielded bioflocculant to the tune of $8.203 \mathrm{~g} / \mathrm{l}$ after purification. Similar account was documented by Zhang et al. [13]. However, the yield with mixed cultures of Methylobacterium sp. Obi and Actinobacterium sp. Mayor reported in this work was lower than those from the consortium of Staphylococcus and Pseudomonas species [13].
The evaluation of bioflocculant concentrations, optimal, for flocculation activity revealed $1 \mathrm{mg} / \mathrm{ml}$ in $100 \mathrm{ml}$ Kaolin clay suspension $(4 \mathrm{~g} / \mathrm{L})$ following the Jar test experimentation (Figure 3). At higher concentrations of bioflocculant, flocculation activity declined and this may be explained as inappropriate interaction of the surfaces charges on the bioflocculant in the medium due to saturation effect consequently, less surface area for binding activity ensured. Better still, the counteractive effect of higher bioflocculant concentration, which disturbs the surface charge distribution, may have accounted for the observation. On a similar note, Chan and Chiang, [19] observed that, when flocculants optimum concentration required for flocculation is exceeded; aggregated particles are re-dispersed thus, disallowing particle settling.

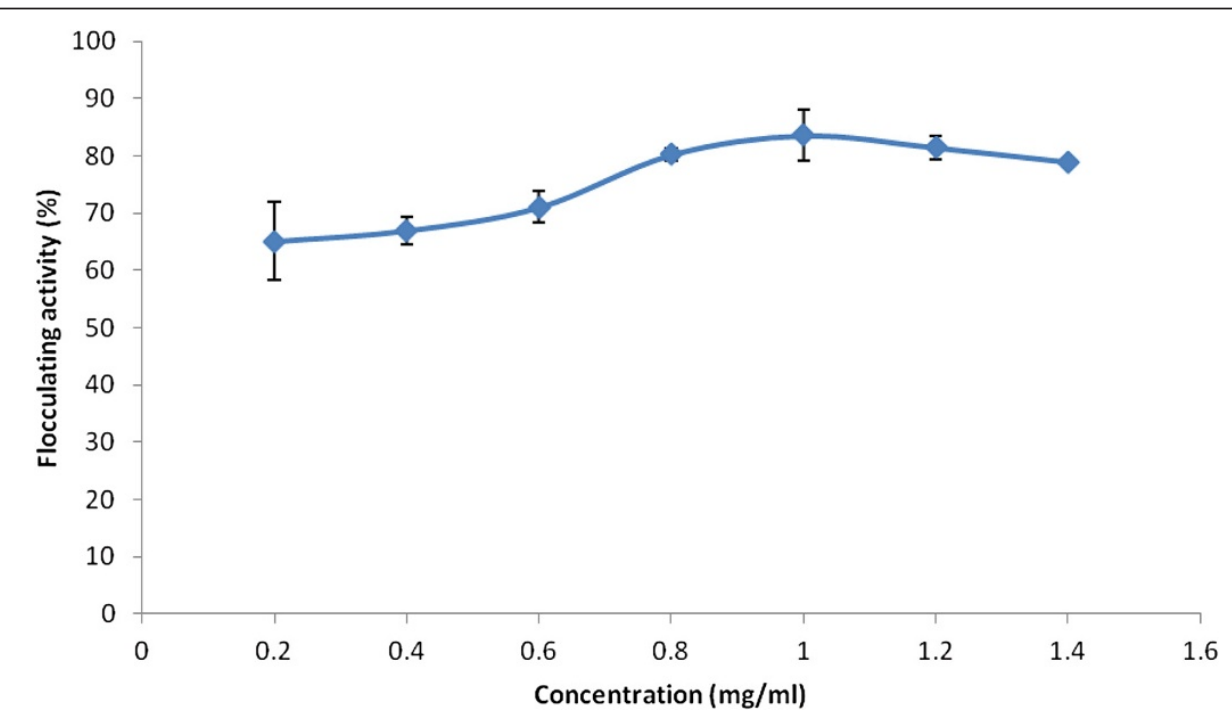

Figure 3 Optimum flocculating activity determination of purified bioflocculant produced by Actinobacterium sp. and Methylobacterium sp. consortium following Jar-test. 


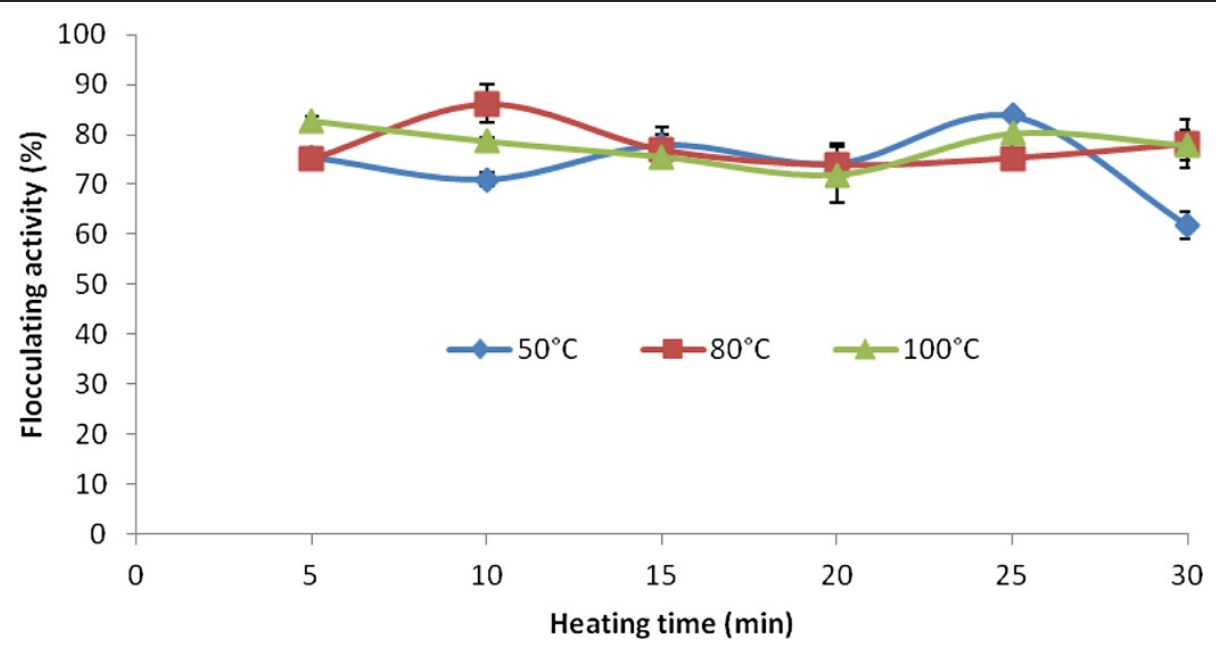

Figure 4 Stability of the purified bioflocculant produced by Actinobacterium sp. and Methylobacterium sp. consortium to different medium temperature.

Nonetheless, optimum concentrations required for flocculation activity are organism dependent; Wang et al. [20] reported $12 \mathrm{mg} / \mathrm{l}$, from the bioflocculant produced by the consortium of Rhizobium radiobacter F2 and $\mathrm{Ba}$ cillus sphaeicus F6, as the optimum concentration required for the flocculation of Kaolin clay in Jar test experimentation. Likewise, Zheng et al. [21] reported $80 \mathrm{mg} / \mathrm{l}$ of bioflocculant produced by Bacillus sp. as optimally causing flocculation of Kaolin clay. Conversely, a lower concentration of $0.3-8.2(\mathrm{mg} / \mathrm{l})$ with flocculation activity at above $90 \%$ [22] was reported for Chryseobacterium daeguese W6.

\section{Flocculation activity of purified bioflocculant - effects of physical-chemical factors}

Subjecting the bioflocculant to different temperature regimes $\left(50^{\circ} \mathrm{C}, 80^{\circ} \mathrm{C}\right.$ and $\left.100^{\circ} \mathrm{C}\right)$ for a period of $30 \mathrm{~min}$ showed thermal stability as flocculation activity was retained. At $80^{\circ} \mathrm{C}$, flocculation activity of $86 \%$ was obtained
(Figure 4). The heat stability of the bioflocculant is remarkable as flocculation activity of more than $70 \%$ was retained at $80^{\circ} \mathrm{C}$ and $100^{\circ} \mathrm{C}$ of the incubation time. The bioflocculant produced by Rhizobium radiobacter F2 and Bacillus sphaeicus F6 [19] consortium was similarly reported to exhibit thermal stability. Temperature tolerance of polymers is important in deciding suitability for water treatment Patil et al. [4].

Adjusting the $\mathrm{pH}$ of the Kaolin clay suspension from acidic to alkaline (3-12) showed recalcitrance to the effects of $\mathrm{H}^{+}$concentration. Flocculating activities of more than $60 \%$ were observed in the $\mathrm{pH}$ range assessed with the highest flocculating activity of $79 \%$ obtained at $\mathrm{pH}$ 11. Similarly, high flocculation activity (76\%) was observed at the acidic $\mathrm{pH}$ of 3 (Figure 5). The reason behind the dual flocculation optimum, at an acidic and alkaline $\mathrm{pH}$ is unclear. However, the weak acidic $\mathrm{pH}$ of 6 was reported as optimum for the bioflocculant produced by the mixed cultures of Staphylococcus and Pseudomonas

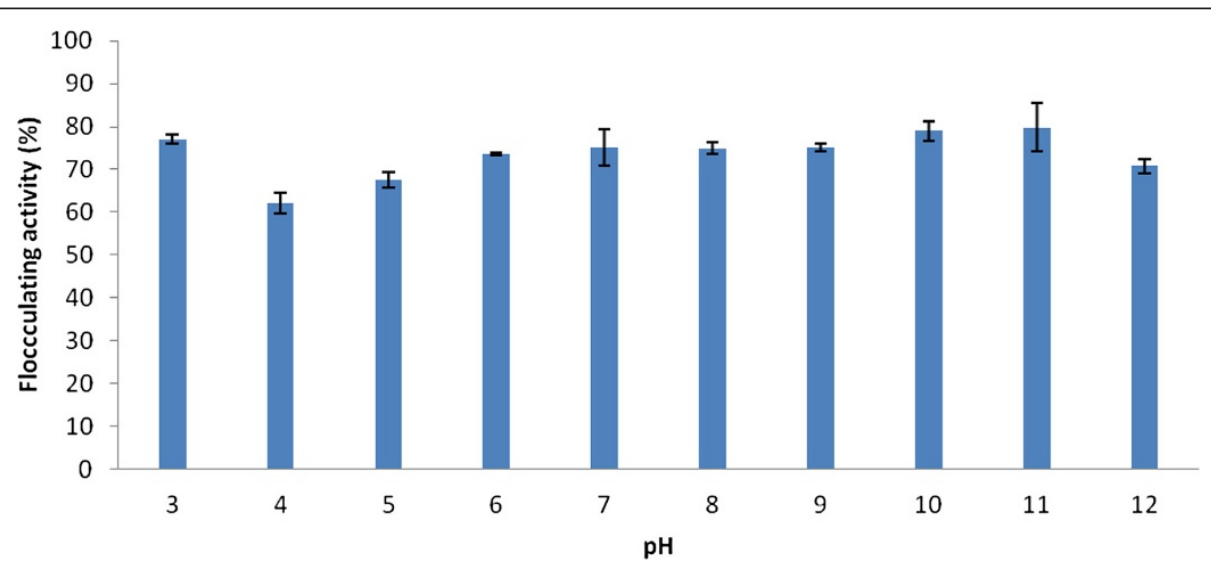

Figure 5 Effect of pH on flocculating activity of purified bioflocculant. 


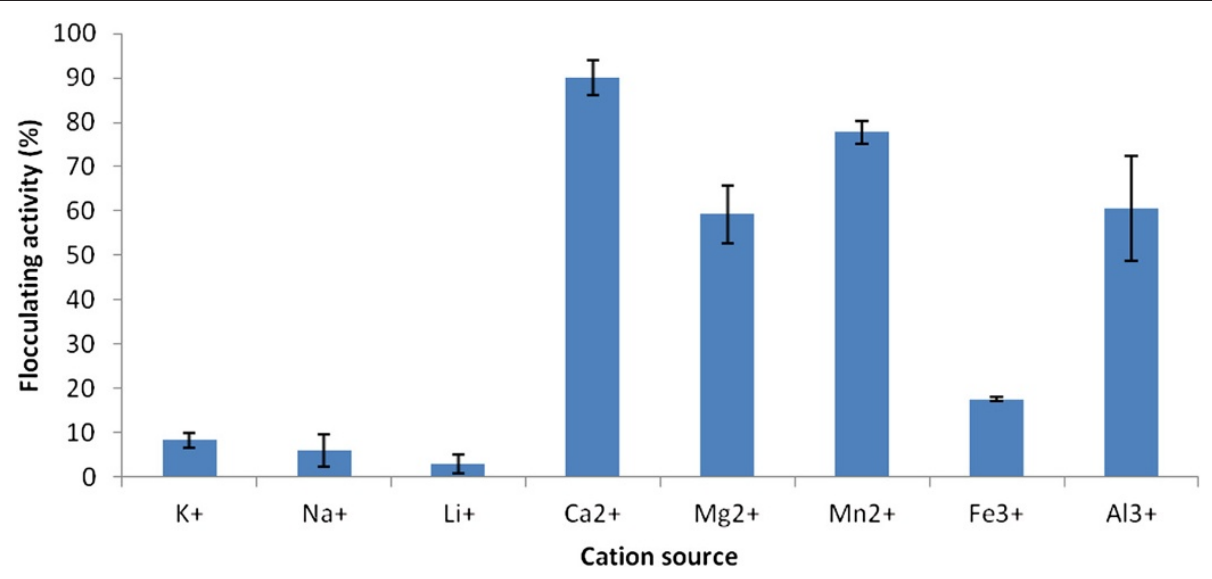

Figure 6 Effect of cation on flocculating activity of purified bioflocculant produced by the consortium.

[13]. Nwodo et al. [18] reported neutral $\mathrm{pH}$ as optimally supporting flocculation activity of purified bioflocculant. Various $\mathrm{pH}$ has been documented to maximally support flocculation activity of bioflocculants [10,20,23].

The assessment of various cations (monovalent, divalent and trivalent) for optimal mediation of flocculation activity of the purified bioflocculant showed the divalent cations of $\mathrm{CaCl}_{2}, \mathrm{MgCl}_{2}$ and $\mathrm{MnCl}_{2}$ to best support flocculation activity. The ions of $\mathrm{CaCl}_{2}$ were best as flocculating activity of $90 \%$ was achieved (Figure 6). Other ion valences have been reported to aid flocculation activity of bioflocculants produced from different microbial species. The bioflocculant produced by the consortium of Oerskovia, Acinetobacter, Agrobacterium and Enterobacter species was optimally supported by $\mathrm{Ca}^{2+}$ in flocculation activity [3]. On the other hand, the trivalent cations of $\mathrm{Al}^{3+}$ and $\mathrm{Fe}^{3+}$ were reported to be more effective in stimulation flocculating activity of a bioflocculant produced by a consortium of Rhizobium radiobacter F2 and Bacillus sphaeicus F6 [19]. The support of various ion valences leading to optimal flocculation activity shown by different bioflocculants may be attributed to their surface properties, particularly the distribution of charges on the surface of the biflocculants.

\section{Compositional analysis of the purified bioflocculant}

Fourier-transform infrared (FTIR) spectrum of the pure bioflocculant showed broad absorption band at $3275 \mathrm{~cm}^{-1}$ and two other sharp bands at 1652 and $1456\left(\mathrm{~cm}^{-1}\right)$, which represents the presence of carboxyl and hydroxyl groups from polymeric and dimeric $\mathrm{OH}$ stretches of phenol or tertiary alcohol bends [19]. The $\mathrm{C}-\mathrm{O}$ stretching vibration band at $1011 \mathrm{~cm}^{-1}$ in conjunction with sharp peak at $849 \mathrm{~cm}^{-1}$ indicates the presence of furan saccharides (Figure 7). Similar spectrum has been reported for bioflocculant produced by other microbial species $[7,24,25]$. These functional groups provide surface charges which serve as the

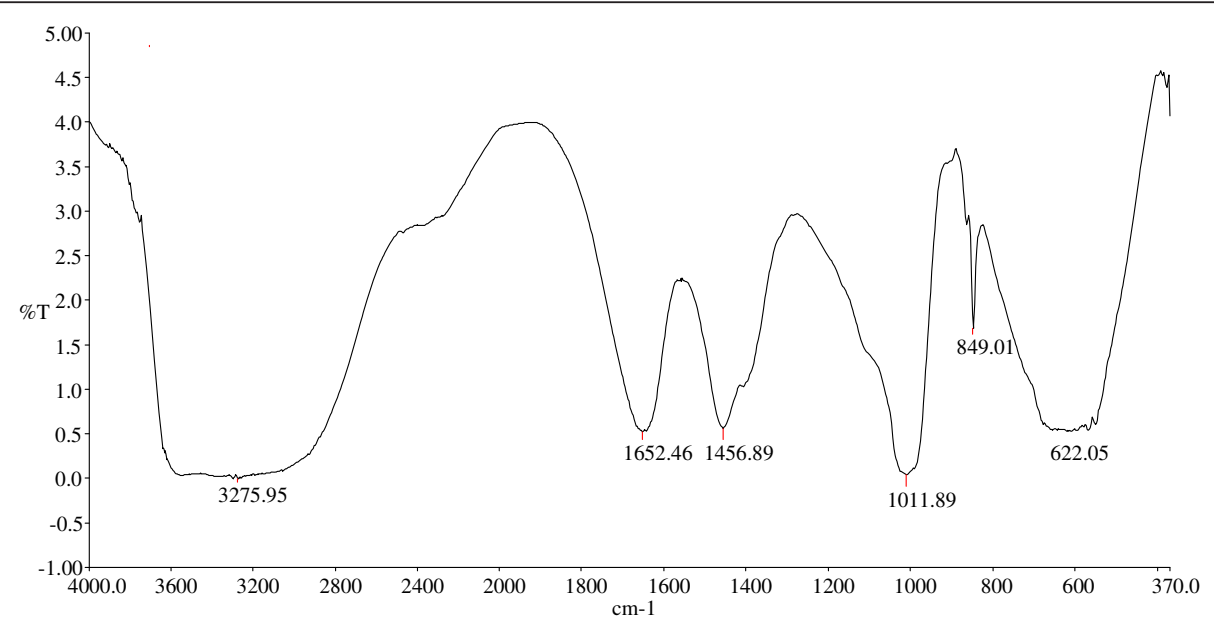

Figure 7 Fourier-transform infrared (FTIR) spectroscopy of purified bioflocculant produced by the consortium. 
binding sites for suspended particles hence, causing aggregation or floc formation in solutions and/or colloids. The roles of $\mathrm{OH}^{-}, \mathrm{COO}^{-}$and $\mathrm{H}^{+}$groups in the flocculation of suspended particles have been reported for several bioflocculants of microbial origin $[26,27]$.

The bioflocculant thermogram revealed an initial weight loss between $20^{\circ} \mathrm{C}$ and $150^{\circ} \mathrm{C}$ and afterwards, other decompositions occurred at $590^{\circ} \mathrm{C}, 700^{\circ} \mathrm{C}$ and $850^{\circ} \mathrm{C}$ respectively. The thermogram profile indicates generic compounds present in the bioflocculant, with proteins and carbohydrates as an integral constituents.

\section{Conclusion}

The bioflocculant produced by the mixed cultures of Methylobacterium sp. Obi and Actinobacterium sp. Mayor is composed of proteins and polysaccharides and probably other constituents which have contributed to the high flocculation of Kaolin clay from the solution. In addition, the mixed culture of Methylobacterium sp. and Actinobacterium sp. have shown good bioflocculant producing potential, following high flocculation activity and bioflocculant yield obtained, in comparison to the yield and flocculation activity shown by the respective axenic cultures. Hence, bioflocculant produced by the consortium has good potentials for industrial applications.

\section{Competing interest}

The authors declare that they have no competing interests.

\section{Authors' contributions}

$\mathrm{NL}$; Executed the experiment, UUN; extracted the data and drafted the manuscript. LVM; and AlO; designed and supervised the research as well as proof read the final version of the manuscript. All authors read and approved the final manuscript.

\section{Acknowledgement}

We express our profound gratitude to the Govan Mbeki Research and Development Center (GMRDC), University of Fort Hare, for funding this research

Received: 3 May 2013 Accepted: 25 July 2013

Published: 1 August 2013

\section{References}

1. Koizumi JI, Takeda M, Kurane R, Nakamura I: Synergetic flocculating of the bioflocculants FIX extracellularly produced by Nocardiaamare. J Gen App/ Microbiol 1991, 37:447-457.

2. Sanayei $Y$, Ismail $N$, Teng $\Pi$, Morad $N$ : Studies on flocculating activity of bioflocculant from closed drainage system (CDS) and its application in reactive dye removal. International J Chem 2010, 2(1):168-173.

3. Kurane $\mathrm{R}$, Matsuyama $\mathrm{H}$ : Production of a bioflocculant by mixed culture. Biosci Biotechnol Biochem 1994, 58:1589-1594.

4. Patil SV, Salunkhe RB, Patil CD, Patil DM: Bioflocculant exopolysaccharide production by Azotobacterinducus using flower extract of Madhucalatifolia L. Appl Biochem Biotechnol 2011, 162:1095-1108.

5. Matthys C, Bilau M, Govaert Y, Moons E, De HS, Willems JL: Risk assessment of dietary acrylamide intake in Flemish adolescents. Food Chem Toxicol 2005, 43:271-278.

6. He N, Li Y, Chen J: Production of a polygalacturonic acid bioflocculant REA11 by Corynebacterium glutamicum. Bioresour Technol 2004, 94:99-105.

7. Salehizadeh $\mathrm{H}$, Shojaosadati SA: Extracellular biopolymeric flocculants recent trends and biotechnological importance. Biotechnol Adv 2011, 19:371-385.
8. Kurane R, Hatamochi K, Kakuno T, Kiyohara M, Hirono M, Taniguchi T: Production of a bioflocculant by Rhodococcus erythropolis S-1 grown on alcohols. Biosci Biotechnol Biochem 1994, 58:428-429.

9. Li Y, He N, Guan H, Du G, Chen J: A polygalacturonic acid bioflocculant REA-11 produced by Corynebacterium glutamicum: a proposed biosynthetic pathway and experimental confirmation. App/ Microbiol Biotechnol 2003, 63:200-206.

10. He J, Zou J, Shao Z, Zhang J, Liu Z, Yu Z: Characteristics flocculating mechanism of a novel bioflocculant HBF-3 produced by deep-sea bacterium mutant Halomonas sp. V3a. J Microbiol Biotechnol 2010, 26:1135-1141

11. Xia S, Zhang Z, Wang X, Yang A, Chen L, Zhao J, Leonard D, JaffrezicRenault N: Production and characterization of bioflocculant by Proteus mirabilis TJ-1. Bioresour Technol 2008, 99:6520-6527.

12. Ma F, Liu JL, Li SG, Yang JX, Zhang LQ, Wu B, Zhu YB: Development of complex microbial flocculant. China Water Wastewater 2003, 19:1-4.

13. Zhang ZQ, Lin B, Xia SQ, Wang XJ, Yang AM: Production and application of a novel bioflocculant by multiple microorganism consortia using brewery wastewater as carbon source. J Environ Sci 2007, 19:667-673.

14. Wang Y, Gao BY, Yue QY, Wei JC, Zhou WZ, Gu R: Color removal from textile industry wastewater using composite flocculants. Environ Technol 2010, 28(6):629-637.

15. Chang WC, Soon AY, In HO, Sang HP: Characterization of an extracellular flocculating substance produced by a planktonic cyanobacterium, Anabaena sp. Biotechnol Lett 1998, 20(12):643-646.

16. Jie G, Hua-ying B, Ming-xia X, Qian L, Yan-fen: Characterization of a bioflocculant from a newly isolated Vagococcus sp. W31. J Zhejiang Univ Sci B 2006, 7(3):186-192.

17. Wang S, Gong W, Lui X, Tian L, Yue Q, Gao B: Production of novel bioflocculant by culture of Klebsiella mobilis using dairy wastewater. $J$ Biochem Eng 2007, 39:81-86.

18. Nwodo UU, Agunbiade MO, Green E, Mabinya LV, Okoh Al: A Freshwater Streptomyces, isolated from Tyume River, produces a predominantly extracellular glycoprotein bioflocculant. Int J Mol Sci 2012, 13:8679-8695.

19. Chan WC, Chiang CY: Flocculation of clay suspensions with water insoluble starch grafting acrylamide/sodium allylsulfonated copolymer powder. Appl Polymer Sci 1995, 58:1721-1726.

20. Wang L, Ma F, Qu Y, Sun D, Li A, Guo J, Guo J, Yu B: Characterization of a compound bioflocculant produced by mixed culture of Rhizobium radiobacter F2 and Bacillus sphaeicus F6. World J Microbiol Biotechnol 2011, 10:1007-1012

21. Zheng Y, Ye Z, Fang X, Li Y, Cia W: Production and characteristics of a bioflocculant produced by Bacillus sp. F19. Biosour Technol 2008, 99:7686-7691.

22. Liu WJ, Wang K, Li BZ, Yuan HL, Yang JS: Production and characterization of an intracellular bioflocculant by Chryseobacterium daeguense W6 cultured in low nutrition medium. Bioresour Technol 2010, 101:1044-1048.

23. Zhi L, Baoping H, Hong L: Optimum condition to high-concentration microparticle slime water with bioflocculants. Mining Sci Technol 2010, 20:0478-0484

24. Suh H, Kwon G, Lee C, Kim H, Yoon B: Characterization of bioflocculant produced by Bacillus sp. DP-152. J Ferment Bioeng 1997, 84:108-112.

25. Kumar CG, Joo HS, Kavali R, Choi JW, Chang CS: Characterization of an extracellular biopolymer flocculant from a haloakalophilic Bacillus isolate. World J Microbiol Biotechnol 2004, 20(8):837-843.

26. Comte S, Guibaud G, Baudu M: Bio sorption properties of extracellular polymeric substances (EPS) resulting from activated sludge according to their type: soluble or bound. Proces Biochem 2006, 41:815-823.

27. Kumar CG, Anand SK: Significance of microbial biofilms in food industry: a review. Int J Food Microbiol 1998, 42:9-27.

doi:10.1186/1472-6750-13-62

Cite this article as: Luvuyo et al: Studies on bioflocculant production by a mixed culture of Methylobacterium sp. Obi and Actinobacterium sp. Mayor. BMC Biotechnology 2013 13:62. 